\title{
Utilization of Curcuma Molases Block to Increase The Performance of Goats that Infected Gastrointestinal Worm at Wonorejo, Wates District, Kediri Regency
}

\section{Pemanfaatan Temulawak Molases Blok untuk Meningkatkan Performance Kambing yang Terinfeksi Cacing Saluran Pencernaan di Wonorejo, Kecamatan Wates, Kabupaten Kediri}

\author{
${ }^{1)}$ Hani Plumeriastuti, ${ }^{2}$ Poedji Hastutiek, ${ }^{2)}$ Lucia Tri Suwanti, ${ }^{3)}$ Wiwik Misaco Yuniarti, ${ }^{3)}$ Nusdianto \\ Triakoso, ${ }^{1}$ Arimbi \\ ${ }^{1)}$ Department of Patology Veteriner, ${ }^{2)}$ Department of Parasitology Veteriner, ${ }^{3)}$ Departmen of Clinic Veteriner, \\ Faculty of Veterinay Medicine, Universitas Airlangga.
}

\begin{abstract}
This was a Community Service activity that aims to share knowladge about utilization of Curcuma Molasses Block (CMB) to increase performance of goats that infected gastrointestinal (GI) parasites to The Goat Breeder Group at Wonorejo, Wates District, Kediri Regency. The activities include: counseling about raising goat management, presentasion on worm diseases that infect goats and $\mathrm{CMB}$ as anthelmentic, workshop and practice to make $\mathrm{CMB}$, detection egg worm in goat's feces, treatment on infected goats and filling out questionnaires evaluating the performance of goat before and after giving CMB. The result show that all of feces samples were positive contain egg worms of Haemonchus contortus, Chabertina ovina, Trichuris globulosa, Strongyloides papillosus, Fasciola gigantica, Trichostrongylus spp., Toxocara sp., and Oesohagustomum columbianum even also protozoans Eimeria sp., and Blastocystis sp. Administration CMB increase performance of worminfected goats which indicated by increase in appetite, soft and shiny hair and the body more wellfed.
\end{abstract}

Key words : Goats, worm diseases, Curcuma Molasses Block.

\section{Pendahuluan}

Pengabdian pada masyarakat ini diadakan berdasarkan program dan kegiatan pengmas yang dikoordinasikan Lembaga Pengabdian Kepada Masyarakat mengacu pada Rencana Strategis Pengmas tahun 2016-2021, Renstra berasaskan kewilayahan, terintegrasi, sinergis, melembaga dan berkelanjutan. Pengmas regional dilakukan di Kabupaten Kediri sebagai salah satu lokasi Kuliah Kerja Nyata (KKN) Mahasiswa Universitas Airlangga. Selanjutnya dipilih Desa Wonorejo, Kecamatan Wates dengan jumlah populasi kambing yang cukup banyak di Kabupaten Kediri. Pemerintah saat ini memberi perhatian khusus pada pengembangan ternak ruminansia kecil seperti kambing dan domba yang diharapkan dapat membantu meningkatkan produksi daging (Nataatmaja dan Arifin, 2008). Ternak merupakan salah satu komoditas potensial dalam pengembangan usaha tani pedesaan, sebagian besar penghasilan peternak kecil berasal dari sumber beternak kambing. Salah satu kendala yang dapat mempengaruhi percepatan pengembangan peternakan di pedesaan adalah penyakit yang dapat menyebabkan kerugian ekonomi karena menurunnya produktivitas ternak bahkan mengakibatkan kematian, dan dampak yang lain adalah menurunnya minat peternak dalam mengembangkan usahanya.

Usaha produksi kambing sebagian besar masih dilakukan secara tradisional. Jumlah kambing di negara tropis sangat banyak, tetapi perhatian yang dicurahkan untuk mengatur perkembangbiakannya sangat sedikit atau bahkan sama sekali tidak ada. Pengembangan peternakan kambing dilakukan dengan meningkatkan populasi dan produktivitas dengan cara Inseminasi Buatan (IB), akan tetapi keberhasilannya dipengaruhi oleh banyak faktor, diantaranya pakan dan penyakit. 
Penyakit akibat infeksi cacing merupakan parasit patogenik yang luas penyebarannya dan tingkat infeksi dapat mencapai $80 \%$. Indonesia yang beriklim tropis basah sangat menguntungkan kelangsungan hidup dan mempermudah penularannya. Penyakit ini sering dilaporkan dan banyak mendatangkan kerugian pada ternak kambing menimbulkan kerugian ekonomi yang sangat besar, meliputi terhambatnya pertumbuhan, penurunan produksi daging dan susu, baik secara kuantitatif maupun kualitatif. Kerugian selain kematian juga menyebabkan terhambatnya pertumbuhan dan produksi daging karena cacing menghisap darah mengakibatkan anemia hemorhagi dengan ditandai penurunan jumlah eritrosit dan PCV. Infeksi kronis dapat berjalan lama karena masih ada sejumlah cacing, jika disertai nutrisi yang jelek maka berakibat penurunan berat badan dan disertai penurunan protein dalam tubuh (Lastuti dkk., 2006). Beberapa jenis telur cacing yang identifikasi dari feses kambing antara lain: Haemonchus sp., Trichuris sp., Oesophagustomum sp, Strongyloides sp, Chabertia (Ilmi dkk., 2019).

Pemanfaatan obat tradisional dianjurkan karena selain dapat menghemat biaya juga dapat mengurangi ketergantungan peternak terhadap obat-obat ternak asal pabrik yang biasanya kurang bahkan tidak tersedia di pedesaan. Selain itu ternak yang sakit dapat segera ditolong karena tumbuhtumbuhan berkhasiat obat banyak tersedia di pedesaan. Kendala pengembangan peternakan di wilayah tersebut yaitu rendahnya pengetahuan tentang pengendalian penyakit parasit menggunakan tanaman obat. Guna meningkatkan penyediaan obat herbal secara kontinyu maka penggunaan tanaman di sekitar pekarangan yang mempunyai khasiat obat diharapkan ini dapat dipakai sebagai obat penyakit parasit cacing dan meningkatkan produktivitas kambing yang dipelihara secara semi intensif dan intensif. Beberapa obat tradisional yang bermanfaat sebagai obat cacing pada ternak kambing antara lain: temulawak, biji lamtoro kering, temu ireng, daun/biji pepaya, buah pinang, akar delima merah, dan kunyit, tanaman ini merupakan tanaman Obat Keluarga (TOGA) yang banyak ditanam oleh masyarakat. Temulawak Moleses Blok (TMB) dapat meningkatkan nilai kecernaan pakan mengobati penyakit cacing pada ternak (Hastutiek dkk., 2016). Diharapkan formula obat herbal salah satu diantaranya dalam bentuk Temulawak Molases Blok membantu pemecahan masalah para peternak yaitu penyediaan obat bermutu dengan harga terjangkau, mudah pembuatannya, mudah pemberiannya, dan dapat memberi keuntungan bagi peternak, disamping itu dapat memberikan kontribusi bagi kesejahteraan para peternak dan dapat menggairahkan usaha beternak kambing sebagai usaha komersial menuju swasembada daging.

Kelompok peternak kambing di Desa Wonorejo, Kecamatan Wates, Kabupaten Kediri merupakan kelompok masyarakat yang belum produktif secara ekonomi tetapi berhasrat kuat untuk menjadi wirausahawan. Sehingga perlu mendapatkan sentuhan kegiatan IPTEK berupa pembuatan Temulawak Molases Blok (TMB). Aplikasi dan inovasi penggunaan tanaman berbasis sumberdaya lokal masih sangat terbatas. Oleh karena itu diperlukan alih teknologi tepat guna kepada peternak kambing dalam Pelaksanaan Kemitraan Masyarakat (PKM) untuk dapat membuat formula obat herbal yang berkhasiat sebagai obat cacing yang dapat meningkatkan performance dan produktivitas kambing serta dapat menekan biaya pengobatan.

Performance adalah aktifitas berupa tingkah laku yang dapat dipelajari atau diamati secara kualitatif, dalam hal ini performance kambing setelah pemberian TMB.

\section{Materi dan Metode}

Tim Pengmas FKH UNAIR membantu peternak kambing di Desa Wonorejo, Kecamatan Wates menyelesaikan permasalahan dengan IPTEKS Temulawak Molases Blok (TMB) untuk mengatasi infeksi cacing saluran pencernaan dengan memanfaatkan tanaman obat yang banyak ditanam oleh peternak. Metode dilakukan dengan memberdayakan peternak yang diarahkan pada kegiatan peningkatan kemampuan sumber daya manusia (SDM), menambah pengetahuan dan ketrampilan dengan memberikan pelatihan pembuatan TMB.

Kegiatan pengmas dilakukan selama 8 (delapan) bulan. Prosedur kerja yang dilakukan meliputi : 1). Pengurusan ijin pada Dinas Ketahanan Pangan Dan Peternakan (DKPP) Kabupaten Kediri, 2). Survey di lokasi pengmas, 3). Tahap pembinaan dilaksanakan penyuluhan dengan mengundang kelompok peternak kambing, penyuluh lapangan, Tim Kesehatan Hewan dari Dinas Ketahanan Pangan Dan Peternakan (DKPP) Kabupaten Kediri, materi diberikan meliputi a). Sistem manajemen 
perkandangan dan cara pemeliharaan ternak kambing yang memenuhi persyaratan kesehatan ternak, b). Sosialisasi tentang penyakit cacing pada kambing dan pengenalan tanaman obat yang berkhasiat sebagai obat cacing, c). Teknik pembuatan TMB dengan teknologi tepat guna sebagai solusi untuk penyakit cacing saluran pencernanan pada kambing. Pengumpulan feses kambing yang dibawa oleh peternak dengan menanyakan gejala klinis, selanjutnya dilakukan pemeriksaan feses dengan metode natif, sedimen dan apung, 4). Tahap pelatihan pembuatan TMB. Temulawak molases blok (TMB) sebagai konsentrat terdiri atas : a) dedak padi/katul, beras jagung, premix (mineral plus) dan tepung temulawak sebanyak 4\%. b) molases sebagai sumber karbohidrat. Bahan-bahan tersebut diatas dicampur sampai homogen selanjutnya dicetak sesuai kebutuhan kemudian di oven, agar tahan lama dan mudah pemberiannya pada kambing (Gambar 1). 5). Tahap Aplikasi, pemberian TMB pada ternak kambing yang terinfeksi cacing sebanyak 25 ekor. Tiap ekor kambing diberikan 1 (satu) bolus TMB dengan berat 200 gram pada pagi hari sebelum diberi hijauan/rumput selama 7 (tujuh) hari. 6). Tahap evaluasi, dilakukan evaluasi dan monitoring serta pengisian quisener untuk melihat serapan materi yang telah diberikan pada tahap pembinaan dan pengukuran performance kambing yang terinfeksi cacing saluran pencernaan setelah diaplikasi dengan TMB.

\section{Hasil dan Pembahasan}

Temulawak sebagai feed additive mempunyai khasiat sebagai antioksidan, curcumin (Didin, 2009 dalam Rachmi dan Wahyuni, 2017) dan anthelmintik karena mengandung xanthorrhizol (Wahyuni dan Retno, 2006 ; Pramudita dkk., 2013). Pemberian TMB ini memberikan manfaat pada kambing diantaranya : secara teknis mudah diberikan, meningkatkan pertumbuhan dan produksi ternak berkualitas baik, mengatasi kebutuhan protein apabila kandungan protein dalam pakan rendah, tidak membahayakan bagi ternak maupun konsumen dan menambah nafsu makan sehingga pertambahan berat badan optimal serta untuk mengobati parasit cacing saluran pencernaan. TMB sebagai pakan tambahan yang lengkap kandungan gizinya, sangat bermanfaat terutama pada ternak kambing yang digemukkan. (Wahyuni, 2009 dan Yanuarto dkk., 2016).

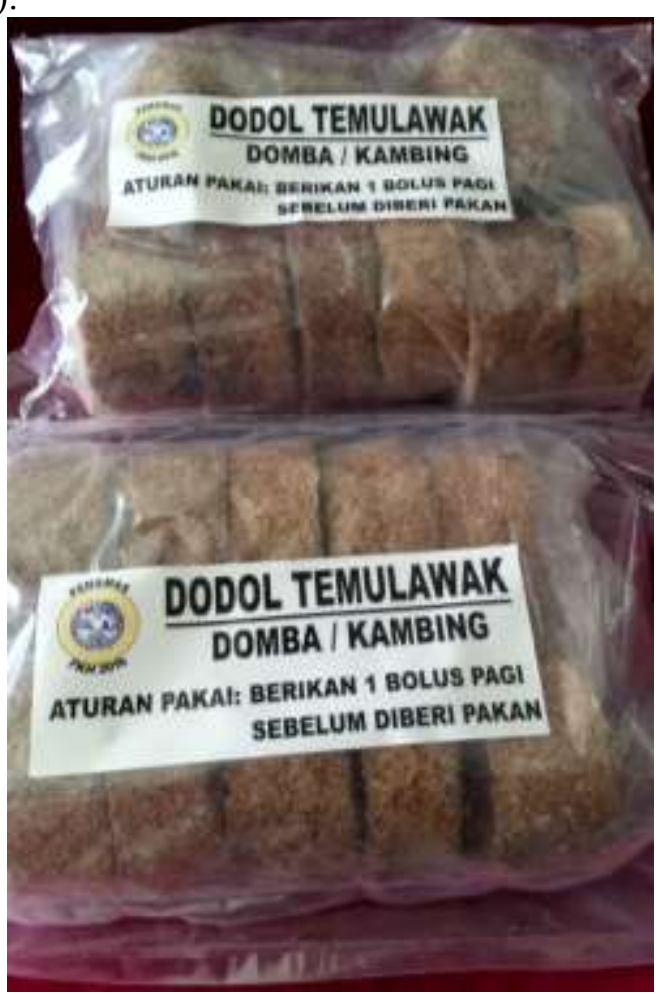

Gambar 1. Temulawak Molases Blok $=$ Dodol Temulawak (Produk Pengmas FKH UNAIR 2018).

Hasil pemeriksaan feses kambing setelah dilihat dibawah mikroskop dengan pembesaran 100x-400x, ditemukan telur cacing Haemonchus contortus, Chabertina ovina, Trichuris globulosa, Strongyloides papillosus, Fasciola gigantica, Trichostrongylus spp., Toxocara sp., Oesohagustomum columbianum dan protozoa yakni Eimeria sp., dan Blastocystis sp.,(Gambar 2).

Hasil analisis quisener menunjukkan bahwa kambing yang terinfeksi cacing saluran pencernaan, setelah diberikan bolus TMB selama 7 (hari) menunjukkan performance secara umum membaik, pengukuran ini secara kualitatif meliputi meningkatnya nafsu makan, berat badan bertambah, tidak ada kerontokan bulu, warna bulu mengkilat, mata tidak berair, konsistensi feses padat dan kambing terlihat lebih lincah. 

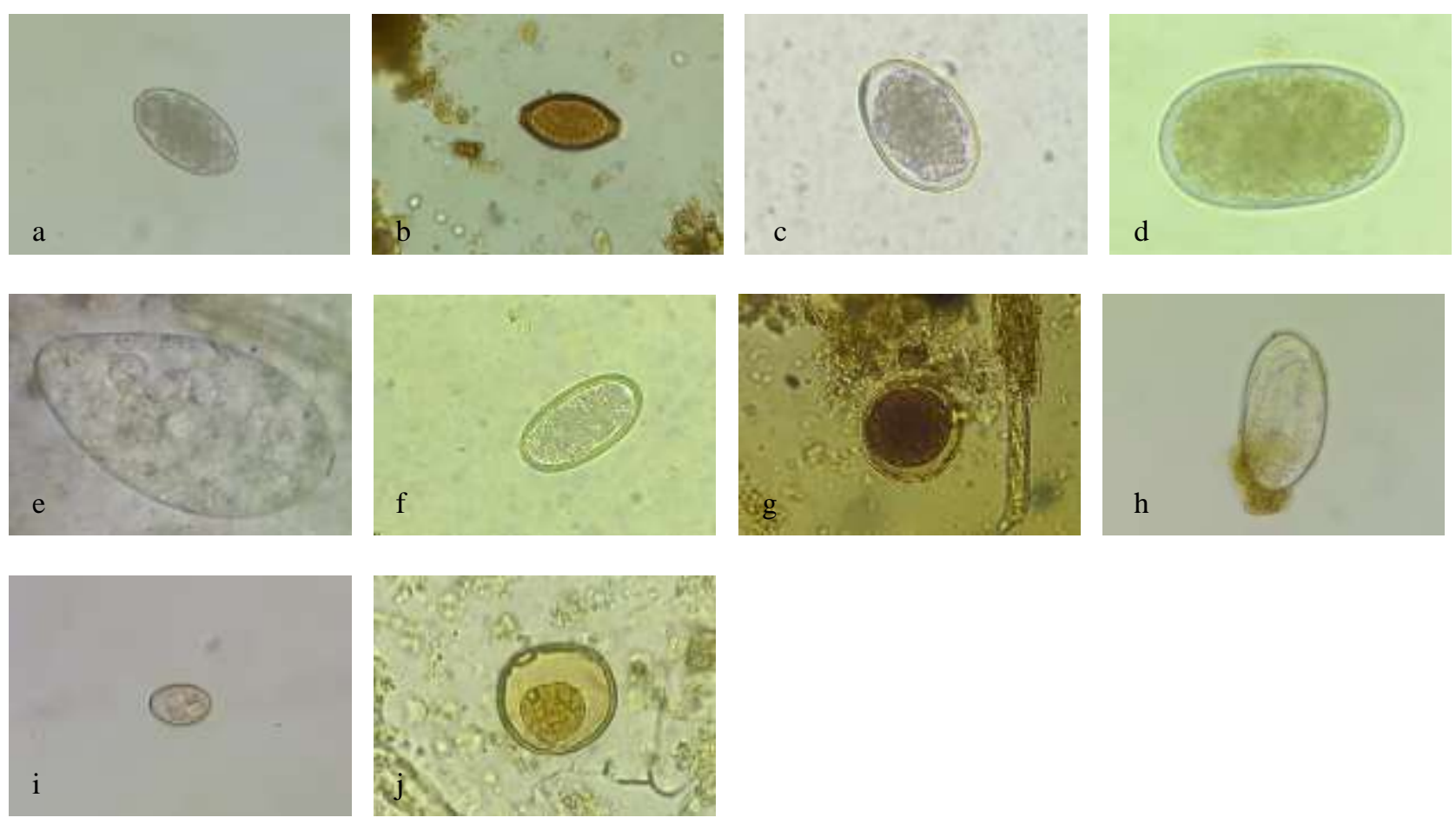

Gambar 2. Jenis-jenis Parasit yang Menginfeksi Kambing di Desa Wonorejo, Kecamatan Wates, Kediri.

a. Haemonchus contortus, b. Trichuris globulosa, c. Oesophagostomum columbianum, d. Chabertia ovina,

e. Fasciola gigantica, f. Trichostrongylus spp., g. Toxocara sp., h. Stronglyoides papillosus, i. Eimeria sp.,

j. Blastocyctis sp.

\section{Kesimpulan}

Temulawak Molases Blok (TMB) memberi manfaat meningkatkan performance kambing yang terinfeksi cacing saluran pencernaan sehingga kambing berdaya jual tinggi dan meningkatkan sumber daya peternak.

Ucapan terima kasih kepada kepala Dinas Ketahanan Pangan Dan Peternakan (DKPP); Drh. Istar Abadi, M.Agr. dan Drh. Carolina Hernawati K.

\section{Referensi}

Hastutiek, P., NDR., Lastuti dan LT. Suwanti 2016. IbM Penggunaan Obat Herbal untuk pengendalian Penyakit Parasit Dalam Rangka Mendukung Program Swasembada Daging Pada Kelompok Peternak di Kecamatan Socah Bangkalan Madura. Laporan Pengmas IbM Direktorat dan Teknologi, Direktorat Jenderal Penguatan Riset dan Pengembangan Kementrian Riset, Teknologi dan Pendidikan Tinggi.

Ilmi, A.F. 2019. Prevalensi dan Derajat Infeksi Helminthiasis pada Saluran Pencernaan Kambing di Kecamatan Kwanyar Kabupaten Bangkalan. [Skripsi]. Fakultas Kedokteran Hewan Universitas Airlangga Surabaya.

Lastuti, N.D.R., Mufasirin dan I. Sahrial. 2006. Deteksi Protein Haemochus sp., pada Domba dan Kambing dengan Uji Dot Blot Menggunakan Antibodi Poliklonal Protein Eksresi dan Sekresi Haemonchus contortus. Media Kedokteran Hewan. 22 (3) : 162-167

Nataatmaja, D.M. dan J. Arifin. 20o8. Karakteristik Ukuran Tubuh dan Reproduksi Jantan pada Kelompok Populasi Domba di Kabupaten Pandeglang dan Garut. Animal Production 10:140-146.

Pramudita, F.E., E. Trisunuwati dan R. Indrati. 2013. Pengaruh Pemberian Serbuk Ekstrak Temu Hitam (Curcuma aeruginosa) dan Temulawak (Curcuma xanthorrhiza) sebagai Antelmentika 
Heterakis gallinarum pada Ayam Petelur. Universitas Brawijaya. Hal. 1-12.

Rachmi, S.E dan R.S. Wahyuni. 2017. Teknologi Complete Feed Herbal untuk Peningkatan Produktivitas Sapi Potong di Kecamatan Parengan Kabupaten Tuban. Agrovet 6 (1). Desember.

Wahyuni R.S., dan R. Bijanti. 20o6. Uji Efek Samping Formula Pakan Komplit terhadap Fungsi Ginjal dan Ginjal Pedet Sapi Freisien Holstein. Media Kedokteran Hewan. 22 (3) : 174-179.
Wahyuni, R.S. 2009. Pengaruh Pemberian Urea Molasses Blok dalam Ransum terhadap Hasil Pemeriksaan laboratorium dan Performan Domba. Laporan Pengabdian kepada Masyarakat LPPM UNAIR, Surabaya.

Yanuarto, A.D. Oktawan, D.H. Tambunan, S. Indarjulianto, A. Nururrozi dan Rusmihayati. 2016. Pengaruh Suplemen Molases Mineral Blok Terhadap Kadar kalsium dan Fosfor Sapi Peranakan Ongole Di Gunung Kidul. Seminar Nasional "Peran Dokter Hewan Dalam Peningkatan Kesehatan Hewan, Lingkungan dan Manusia”. FKH UGM Yokyakarta 17 September 2016. 